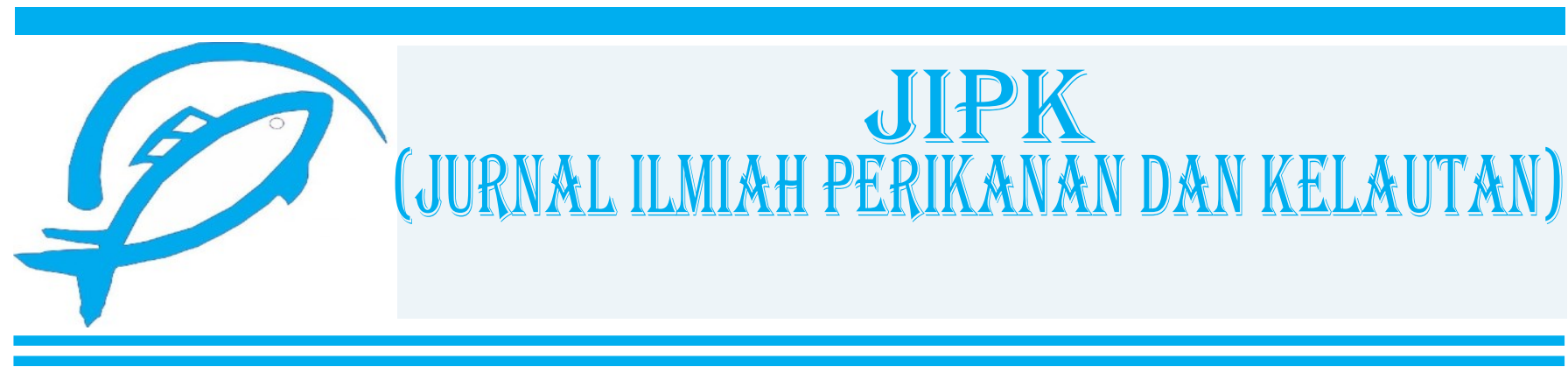

Short Communication

\title{
Preliminary Research: Utilization of Gourami Fish Bone Flour (Osphronemus gouramy) in Making Calcium Dumplings
}

\author{
Dwi Lestari Handayani, 2* (D), Monicha Efi Sumaimi, Tri Ani Ashari, and Jumadi \\ Science Education Study Program, Postgraduate Program, Yogyakarta State University Jalan Colombo No. 1, Karangmalang, \\ Yogyakarta 55281, Indonesia
}

\section{OPEN}

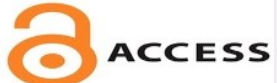

\section{ARTICLE INFO}

Received: Juny 02, 2020

Accepted: July 05, 2020

Published: September 27, 2020

*) Corresponding author:

E-mail: dwilestaria21@gmail.com

Keywords:

Gourami

Fish bone

Calcium Flour

Dumplings

This is an open access article under the CC BY-NC-ND license (http://creativecommons.org/licenses/by-nc-nd/4.0/)

\begin{abstract}
Gourami (Osphronemus gouramy) is a type of freshwater fish native to Indonesia that is widely preferred, and has high economic value so that production per year increases. Increasing the amount of fish production will result in an increased amount of fish bone waste. However, the processing of gourami in general is still limited to using the meat for frying, grilling, filling, and making shredded fish, while the fish bones are not widely used. Several studies have shown that fish bones that are made into flour contain high calcium. Food processing from fish bone flour can be used as an alternative to meet daily calcium intake. Several studies have started to use fish bone flour to become processed food with calcium such as baked donuts, starch balls, and biscuits, but there are still many other foods from the different regions that need to utilize the fish bone as one of their ingredients. The purpose of this study was to analyze the understanding of the community members, and newcomers in Purbalingga regarding the use of fish bone flour, and its processed products, calcium content, also to know their favorite snacks, and types of fish. The results of the survey analysis stated that it is necessary to use Gourami fish bone flour in making calcium dumplings and its resistance to oxygen
\end{abstract}

Cite this as: Handayani, D. L., Sumaimi, M. E., Ashari, T. A., \& Jumadi. (2020). Preliminary Research: Utilization of Gourami Fish Bone Flour (Osphronemus gouramy) in Making Calcium Dumplings. Jurnal Ilmiah Perikanan dan Kelautan, $12(2): 302-307$. http://doi.org/10.20473/jipk.v12i2.19572 


\section{Introduction}

Gourami (O. gouramy) is a type of freshwater fish native to Indonesia which is cultivated in ponds. Gourami is one of the important economic commodities of cultivated fish which is known, and favored by the community because the meat has a delicious taste with a distinctive taste (Hardaningsih, 2018; Nugraha et al., 2020; Budi et al., 2015; Slembrouck et al., 2019). The delicious taste of gourami meat and its high nutritional content is very beneficial for growth and energy formation (Nugroho et al., 2014). In addition to being widely preferred, gourami, the price is relatively higher than other types of fish that are commonly market- ed, therefore it has a high economic value (Nugroho, 2012). Based on data from the Directorate General of Aquaculture, Ministry of Marine Affairs, and Fisheries (2019), it was noted that the production of gourami from 2015-2019 showed an average increase of $24.75 \%$ per year. Increased production of gourami will result in an increased amount of bone waste.

The processing of gourami in general is still limited to using the meat for frying, grilling, filling, and making shredded fish, while the fish bones themselves are not widely used. One of the uses of gourami bones is the extraction of collagen from bones and scales (Tridhar, 2016). According to Amitha et al. (2019); Asikin et al. (2019) stated that to minimize environmental pollution, and fish bone waste, it can be done by using it as fish bone flour or a source of food calcium which can provide added value. Fish bones are the part that has the highest calcium content among fish body parts, because the main constituents of fish bones are a source of important minerals: sodium, calcium $(5.63 \mathrm{~g} / \mathrm{kg})$, phosphorus $(2.38 \mathrm{~g} / \mathrm{kg}$ ), and carbonate (Sinaga et al., 2018; Hemung, 2013; Stanek et al., 2013). When compared to mackerel fish bones, gourami bones have a higher calcium content (Amalina, 2019). Calcium compounds from fish bones have high bioavailability, so that they have the potential to be a natural source of calcium such as food, feed or supplements (Malde et al., 2010a; Boutin- guiza et al., 2012, Yin et al., 2016; Malde et al., 2010b).

The use of fish bone waste in food is made of flour containing calcium (Wardani et al., 2013). Several studies have shown that there is a high level of calcium contained in fish bone flour. Putranto et al. (2015) tested calcium levels using the protein hydrolysis method in belida fish bone flour (Chitala $\mathrm{sp}$ ), the highest calcium was $30.93 \%$ with a yield of $27.77 \%$. Marasabessy et al. (2018) tested the calcium content using the deproteinase method, the highest calcium was found in snapper flour at 29.42\%. Angraini et al. (2019) tested calcium levels with an experimental method on catfish, catfish and sembilang bone flour, obtained calcium of $51.3 \%$, $65.9 \%$, and $38.4 \%$. This means that fish bones that are made into powdered flour can be used as food and calcium supplements to meet daily calcium needs (Bin et al., 2013; Jeyasanta et al., 2013). The recommended daily calcium requirement according to the Regulation of the Minister of Health of the Republic of Indonesia No. 28 of 2019 is $1,000 \mathrm{mg}$ for adults over 25 years, and $1,200 \mathrm{mg}$ after the age of 50, pregnant, and lactating women should consume $+200 \mathrm{mg}$ of calcium per day. The calcium needs of children, and adolescents increase according to age.

Food processed from fish bone flour can be used as an alternative to meet daily calcium intake. Bachtiar et al. (2019) utilized milkfish bone flour as a source of calcium, and phosphorus in making baked donuts. Susanto et al. (2019) have used tuna bone waste flour as a source of calcium to make starch balls. Akhmadi et al. (2019) have also used milkfish bone flour in making biscuits. From the three, it was found that the higher the concentration of fish bone flour given a high calcium content. Meanwhile, the level of preference for grilled donuts, starch balls, and biscuits depends on the concentration of adding fish bone flour. This means that in addition to being an alternative for the fulfillment of calcium, processed fish bone flour also has its own characteristics related to taste, color, aroma, and texture of donuts, starch balls, and biscuits. The concentration of adding fish bone flour needs to be considered so that the calcium content, and physical characteristics of the processed food do not decrease. Based on some of the descriptions above, other food processing that can take advantage of processed regional food are needed, for this purpose the purpose of this study is to analyze the understanding of the community and newcomers in Purbalingga regarding the use of fish bone flour and its processed products, calcium content, as well as snacks and types of fish that are popular.

\section{Materials and Methods}

\subsection{Material}

This research used the main ingredient in the form of gourami bones (O. gouramy) from head to tail obtained from the Purbalingga fish market.

\subsection{Experimental design}

This research was an initial stage of experimental research related to the use of gourami ( $O$. gouramy) bone flour in making calcium dumplings in Purbalingga, Central Java. This preliminary research was conducted using a survey research method through an online google form questionnaire that was distributed to community members and newcomers in Purbalingga, 
Central Java. The experimental research was carried out in three stages, namely the stage of making gourami fish bone flour, the stage of making dumplings with the addition of variations in the measurement of gourami fish bone flour, as well as the stages of testing calcium levels, and hedonic tests. The experimental research used experimental methods with two treatments (steamed and fresh), four variations in the concentration of gourami fish bone flour $(0 \%, 10 \%, 15 \%$, and $20 \%)$, and the repetition of each variation was carried out three times, along with several random selected panelists.

The stages of making gourami bone flour referred to the modified method (Susanto et al., 2019). Gourami bones from the head, back to tail were washed clean from the remaining meat, and boiled for 45 minutes to remove fat. Furthermore, two treatments were carried out, namely the non-steaming method (fresh sample after boiling) and the steaming method (the sample after boiling was steamed for two hours). The next process, the fresh sample was cut into the segments of the fish bones. Fresh samples and steamed samples were then dried in the sun to dry, and the dried gourami bones were mashed in a blender or grounded until smooth. Furthermore, gourami bone flour was sieved using a sieve to obtain the desired flour.

\subsection{Making gourami fish bone flour dumplings}

The stages of making this gourami fish bone flour dumplings namely by refining the spices, mixing all the ingredients together with each varying the concentration of gourami fish bone flour, and stirring until blended. Next, heating the steamer, and adding the dumplings to be steamed, then steaming the dumplings for 20-25 minutes.

\subsection{Calcium level test and hedonic test}

The parameter to be observed was the calcium level test using AAS (Atomic Absorption Spectrophotometry) in the chemistry laboratory of Yogyakarta State University with the method used (Akhmadi et al., 2019) by weighing 0.1 gram of gourami fish bone flour, and putting it in a Kjeldahl flask as much as $100 \mathrm{ml}$, and added $15 \mathrm{ml}$ of HCL (hydrochloric acid), the solution was then digested until it was clear, and cooled. After chilling, the results of the digestion were filtered until the volume of the filter results was $100 \mathrm{ml}$, and ready to be measured at AAS with a wavelength of $420 \mathrm{~nm}$. Hedonic test (level of preference for texture, color, taste, and aroma) through an assessment form.

\subsection{Data Analysis}

The results of calcium levels was analyzed as the method used (Susanto et al., 2019) using the Standard Error of Mean (SEM) with the help of Microsoft Excel 2013, and the results of the hedonic test was described descriptively.

\section{Results and Disccussion}

The results obtained from an online survey using google form which were distributed to residents, and newcomers in Purbalingga, Central Java regarding the use of gouramy fish bone flour (O. gouramy) discussed the use of fish bone flour, and its processed products, calcium content, as well as snacks, and types of fish which was popular. The distribution for seven days obtained 150 respondents who filled out the questionnaire well. The results of the questionnaire analysis can be seen in Table 1 .

Table 1 contains the results of the analysis regarding the understanding of the community members, and newcomers in Purbalingga regarding the use of fish bone flour, and its processed products. It could be seen that the use or processing of fish bone flour is still limited to the addition of animal feed, and food processing was still limited to process pempek. There was still little understanding of fish bones which could be used as calcium flour, whereas when viewed from the opinion that had tried food made from fish bone- flour, it was stated that it is savories and more delicious. Bachtiar et al. (2019) had used milkfish bone flour as a source of calcium, and phosphorus in making baked donuts, it was found that in addition to being an alternative for calcium fulfillment, the addition of milkfish bone flour also provided its own characteristics related to taste, color, aroma, and texture of the donuts. However, it was still necessary to pay attention to the concentration of adding fish bone flour, therefore it did not affect the physical characteristics of the food.

Edam (2016) conducted fortification of the piercing fish bone flour on its physical characteristics, it was found that it had an effect on reducing the bite test of fish balls., contains the results of an analysis of the understanding of community members, and new comers in Purbalingga regarding calcium content. It appeared that almost the majority of respondents already knew what calcium was even though they did not know how much calcium the body needs every day. The recommended daily calcium requirement according to the Regulation of the Minister of Health of the Republic of Indonesia No.28 of 2019 is $1000 \mathrm{mg}$ for adults over 25 years, and $1,200 \mathrm{mg}$ after the age of 50 years, pregnant, and lactating women should consume $+200 \mathrm{mg}$ of calcium per day and calcium needs for children and adolescents increased with age. Meanwhile, the daily calcium needs of most respondents had met so they know that fish flour also contains calcium. Calcium could be obtained from dairy products, cheese, supplements or products that were fortified with calcium (Miller et al., 2013). According to the International Osteoporosis Foundation (2017) that aparted from milk, and its processed products, you could also obtain calcium from other foods such as green vegetables, nuts, tofu, salmon, sardines, and food and beverage products that had been fortified with calcium. 
Table 1. Analysis of the understanding of citizens and migrants in Purbalingga regarding the use of fish bone flour and processed products.

\begin{tabular}{|c|c|c|}
\hline No & Aspects to observe & Result \\
\hline 1 & Food processing from fish flour & $\begin{array}{l}\text { Of the } 150 \text { respondents, it was found that } 14 \% \text { or } 21 \\
\text { respondents had tried to process food from fish flour } \\
\text { and } 86 \% \text { or } 129 \text { other respondents had never done it. }\end{array}$ \\
\hline 2 & $\begin{array}{l}\text { Utilization or processing of fish } \\
\text { bones }\end{array}$ & $\begin{array}{l}11.3 \% \text { ( } 17 \text { respondents) of } 150 \text { respondents used or } \\
\text { processed fish bones and } 86.7 \% \text { ( } 133 \text { respondents) had } \\
\text { never used it. The average utilization or processing of } \\
\text { fish bones that was carried out was as a craft, } \\
\text { additional livestock feed, cat food, and fish cake } \\
\text { processing. }\end{array}$ \\
\hline 3 & $\begin{array}{l}\text { Understanding of fish bones into } \\
\text { calcium flour }\end{array}$ & $\begin{array}{l}\text { The understanding of fish bones that could be used as } \\
\text { calcium flour was still low, namely only } 34.7 \% \text { of } \\
\text { respondents already knew, while the remaining } 65.3 \% \\
\text { did not know. }\end{array}$ \\
\hline 4 & $\begin{array}{l}\text { Consumption of food made of fish } \\
\text { bone flour }\end{array}$ & $\begin{array}{l}\text { Consumption of food that came from added fish bone } \\
\text { flour was still small, of the } 150 \text { respondents, only } 24 \\
\text { respondents ( } 16 \%) \text { had tried it. The average response } \\
\text { to food with the addition of fish bone flour was tastier } \\
\text { and savorier. }\end{array}$ \\
\hline
\end{tabular}

Table 2. Analysis of the understanding of citizens, and newcomers in Purbalingga regarding calcium content

\begin{tabular}{|c|c|c|}
\hline No & Aspects to observe & Result \\
\hline 1 & $\begin{array}{l}\text { Understanding of mineral samples } \\
\text { that the body needs }\end{array}$ & $\begin{array}{l}\text { Based on the survey results, } 98 \% \text { or it could be said } \\
\text { that most of the } 150 \text { respondents understood that } \\
\text { calcium was a mineral that the body needs. }\end{array}$ \\
\hline 2 & $\begin{array}{l}\text { An understanding of the amount of } \\
\text { calcium the body needs }\end{array}$ & $\begin{array}{l}\text { Respondents' understanding of the amount of calcium } \\
\text { The body's needs were still low where } 76.7 \% \text { of } 150 \\
\text { respondents did not know and only } 23.3 \% \text { do. }\end{array}$ \\
\hline 3 & $\begin{array}{l}\text { Understanding the diet required } \\
\text { daily calcium }\end{array}$ & $\begin{array}{l}\text { Of the } 150 \text { respondents, } 103 \text { respondents stated that } \\
\text { they consumed foods containing calcium every day } \\
\text { such as milk, fish and supplements. The rest, namely } 47 \\
\text { respondents, did not consume it every day. }\end{array}$ \\
\hline 4 & $\begin{array}{l}\text { Understanding of fish flour contains } \\
\text { calcium }\end{array}$ & $\begin{array}{l}\text { Some of the respondents }(54.7 \%) \text { of the } 150 \\
\text { respondents had understood that fish flour contained } \\
\text { calcium and } 45.3 \% \text { or } 68 \text { respondents did not know. }\end{array}$ \\
\hline
\end{tabular}

Table 3. Analysis of snacks and fish species favored by residents and newcomers in Purbalingga

\begin{tabular}{|c|c|c|}
\hline No & Aspects to observe & Result \\
\hline 1 & Favorite snacks and why & $\begin{array}{l}\text { The most popular snacks for residents and newcomers } \\
\text { in Purbalingga were dumplings }(35.3 \%) \text {, meatballs } \\
(21.3 \%) \text {, and batagor }(11.3 \%) \text {. Most of the } \\
\text { respondents stated that this favorite snack was } \\
\text { delicious, tasty, and cheap. }\end{array}$ \\
\hline 2 & $\begin{array}{l}\text { Popular types of fish and their } \\
\text { reasons }\end{array}$ & $\begin{array}{l}\text { The types of fish most favored by residents and } \\
\text { newcomers in Purbalingga are Grouper }(44 \%) \text {, catfish } \\
(10 \%) \text {, and milkfish }(9.3 \%) \text {. Most of the respondents } \\
\text { stated that these popular types of fish was delicious, } \\
\text { easy to process, and nutritious. }\end{array}$ \\
\hline
\end{tabular}


JIPK. Volume12 No 2. November 2020 / Preliminary Research: Utilization of Gourami Fish Bone Flour in Making Calcium...

Table 3 contains the processed food and the type of fish that is preferred. It could be seen that respondents liked and often consumed processed dumplings, meatballs, and batagor because they were cheap, delicious, and tasty. Meanwhile, dumplings were the type of food processed most favored by residents, and newcomers in Purbalingga. Meanwhile, the fish preferred by some respondents was gourami because it was delicious, easy to process, and cheap. The three results of the online questionnaire analysis were related to each other. Prior to food processing, and the preferred type of fish to be used as variables in further research, it was necessary to know the respondents' understanding regarding the use of fish bone flour and its processed products, and calcium content. This was because further research was related to the use of fish bone flour in the process of calcium-rich foods.

\section{Conclusion}

The results of the survey and analysis regarding the understanding the use of fish bone flour, and its processed products, calcium content, as well as snacks, and types of fish favored concluded that it is necessary to process or use gourami bone flour in making calcium dumplings in Purbalingga, and how much oxygen resistance is needed, this is to help meet the daily amount of calcium through processed foods.

\section{Acknowledgement}

We thank to respondents for his participation "fill out the survey".

\section{Authors' Contributions}

All authors have contributed to the final draft. The contributions of each writer are as follows, DLH compiles the text and conceptualized the main idea, MES helps collect data, TA corrects the article script, and $\mathrm{J}$ provides input and improvement.

\section{Conflict of Interest}

We declare that we have no competing interests.

\section{Funding Information}

This research was not funded, self-funded.

\section{References}

Akhmadi, M. F., Imra, \& Maulianawati, D. (2019). Fortifikasi kalsium dan fosfor pada crackers dengan penambahan tepung tulang ikan bandeng (Chanos chanos). Jurnal Ilmiah Perikanan dan Kelautan, 11(1): 49-54.

Amalina, L.R. (2019). Analisis kadar kalsium ( $\mathrm{Ca}$ ) dan fosfor $(P)$ tepung tulang ikan tenggiri
(Scomberomorus comerson) dan ikan gurami (Osphronemus gouramy) di Kabupaten Jember. Jember: UT-Faculty of Dentistry.

Amitha, Raju, C. V., Lakshmisha, I. P., Kumar, P. A., Sarojini, A., Endra, G., \& Pal, J. (2019). Nutritional composition of fish bone powder extracted from three different fish filleting waste boiling with water and an alkaline media. International Journal of Current Microbiology and Applied Sciences, 8(02): 2942-2948.

Angraini, R. M., Desmelati, \& Sumarto. (2019). Karakteristik mutu tepung tulang ikan dari jenis ikan berbeda (ikan patin, lele dan sembilang). Jurnal Berkala Perikanan Terubuk, 47(1): 69-75.

Asikin, A. N., Kusumaningrum, I., \& Hidayat, T. (2019). Effect of knife-fish bone powder addition on characteristics of starch and seaweed kerupuk as calcium and crude fiber sources. Current Research in Nutrition and Food Science Journal, 7(2): 589591.

Bakhtiar, Rohaya, S., \& Ayunda, H. M. (2019). Penambahan tepung tulang ikan bandeng (Chanos chanos) sebagai sumber kalsium dan fosfor pada pembuatan donat panggang. Jurnal Teknologi dan Industri Pertanian Indonesia, 11(1): 38-45.

Bin, M. I, Dara, A., Sontang, M., Zuha R., \& Marlini, A. N.(2013). Fish bone waste utilization program for hydroxyapatite product; a case study of knowledge transfer from a university to coastal communities. Journal of Environmental Research and Development, 7(3): 1-8.

Boutinguiza, M., Pou, J., Comesaña, R., Lusquiños, F., de Carlos, A., \& León, B. (2012). Biological hydroxyapatite obtained from fish bones. Materials Science and Engineering,32(3): 478-486.

Budi, D. S., Alimuddin, \& Suprayudi, M. A. (2015). Growth response and feed utilization of giant gourami (Osphronemus goramy) Juvenile feeding different protein levels of the diets supplemented with recombinant growth hormone. Journal of Biosciences, 22(1): 12-19.

Edam, M. (2016). Fortifikasi tepung tulang ikan terhadap karakteristik fisiko-kimia bakso ikan. Jurnal Penelitian Teknologi Industri, 8(2): 83-90.

Hardaningsih, I. (2018). Budidaya gurami untuk ketahanan pangan dan eradiksi kemungkinan di pedesaan: peluang dan tantangan. Yogyakarta: Departemen Perikanan Fakultas Pertanian UGM.

Hemung, B. O. (2013). Properties of Tilapia bone powder and its calcium bioavailability based on transglutaminase assay. International Journal of Bioscience, Biochemistry and Bioinformatics, 3(4): 306-309.

International Osteoporosis Foundation. (2017). Good nutrition for healthy bones. Switzerland: International Osteoporosis Foundation. 
Jeyasanta, K. I, Aiyamperumal, V., \& Patterson, J. (2013). Utilization to trash fishes as edible fish powder and its quality characteristics and consumer acceptance. World Journal of Food Science and Technology, 8(1): 1-10.

Malde, M. K., Bügel, S., Kristensen, M., Malde, K., Graff, I. E., \& Pedersen, J. I. (2010a). Calcium from salmon and cod bone is well absorbed in young healthy men: a doubleblinded randomised crossover design. Nutrition \& Metabolism, 7(1): 61-69.

Malde, M. K., Graff, I. E., Siljander-Rasi, H., Venalainen, E., Julshamn, K., Pedersen, J. I., \& Valaja, J. (2010b). Fish bones - ahighly available calcium source for growing pigs. Journal of Animal Physiology and Animal Nutrition, 94(5):66-76.

Marasabessy, I., Sudirjo, F., \& Nara, S. (2018). Karakteristik tepung tulang ikan pelagis dan demersal sebagai sumber kalsium. Jurnal Ilmiah Inovasi, 18(3): 133-136.

Miller, G. D., Jarvis, J. K., \& McBean, L. D. (2013). Review: The importance of meeting calcium needs with foods. Journal of the American College of Nutrition, 20(2): 168S-185S.

Minister of Health of the Republic of Indonesia (2019). Peraturan Menteri Kesehatan Republik Indonesia Nomor 28 Tahun 2019 tentang angka kecukupan gizi yang dianjurkan untuk masyarakat Indonesia. Jakarta: Kementerian Kesehatan Republik Indonesia.

Ministry of Marine Affairs and Fisheries. (2020). Laporan kinerja 2019. Jakarta: Direktorat Jenderal Perikanan Budidaya Kementerian Kelautan dan Perikanan.

Nugraha, A. A., Yustiati, A., Bangkit, I., \& Andriani, Y. (2020). Growth performance and survival rate of giant gourami fingerlings (Osphronemus goramy Lacpede, 1801) with potassium diformate addition. World Scientific News, 143(1): 103-114.

Nugroho, E. (2012).'Endang Pamularsih' gurame yang jempolan. Media Akuakultur, 7(2): 99-102.
Nugroho, D.A., Darmanto, Y.S., \& Romadhon. (2014). Pengaruh cara kematian ikan dan tahapan penurunan dan kondisi kesegaran ikan terhadap kualitas pasta ikan gurami (Osphronemous gouramy). Jurnal Pengolahan dan Bioteknologi Hasil Perikanan, 3(3): 61-67.

Putranto, H. F., Asikin, A. N., \& Kusumaningrum, I. (2015). Karakterisasi tepung tulang ikan belida (chitala sp.) sebagai sumber kalsium dengan metode hidrolisis protein. Ziraa'ah, 40(1): 11-20.

Sinaga, I.B., Harahap, L.A., \& Ichwan, N. (2018). Karakteristik tepung tulang yang dihasilkan berbagai bahan baku yang diolah dengan alat penggiling tulang. Jurnal Rekayasa Pangan dan Pertanian, 6(1): 181-185.

Slembrouck, J., Arifin, O. Z., Pouil, S., Subagja, J., Yani, A., Kristanto, A. H., \& Legendre, M. (2019). Gender identification in farmed giant gourami (Osphronemus goramy): a methodology for better broodstock management. Aquaculture, 498: 388395.

Stanek, M., Peter, E., \& Janicky, B. (2013). Content of the calcium and phosphorus in the meat of Prussian carp (Carassius auratusgibelio BLOCH, 1783) from the Lake Gopło (Poland). Journal of Central European Agriculture, 14(1): 1-10.

Susanto, A. H., Ridho, R., \& Sulistiono. (2019). Pemanfaatan limbah tulang ikan tuna dalam pembuatan cilok sebagai sumber kalsium. Lemuru Jurnal Ilmu Perikanan dan Kelautan Indonesia, 1(1): 25-33.

Tridhar, N. A. (2016). Perbandingan produksi kolagen dari sisik dan tulang ikan gurami (Osphronemus gouramy) secara kimia enzimatis. Bandung: Program Studi Teknologi Pangan Universitas Pasundan.

Wardani, D. P., Liviawaty, E., \& Junianto. (2013). Fortifikasi tepung tulang tuna sebagai sumber kalsium terhadap tingkat kesukaan donat. Jurnal Perikanan dan Kelautan, 3(4): 41-50

Yin, T., Du, H., Zhang, J., \& Xiong, S. (2016). Preparation and characterization of ultrafine fish bone powder. Journal of Aquatic Food Product Technology, 25(7): 1045-1055. 